\title{
金-白金双極電極を用いるサイクリックボルタンメト リーによる塩化物イオンの定量
}

\author{
尾崎 武二 ${ }^{\circledR}$, 平山 和雄 , 宇野原信行*
}

(1989 年 4 月 19 日受理)

\begin{abstract}
金作用電極及び白金対極を組み合わせた双極電極を用いて，サイクリックボルタンメトリーによる塩 化物イオンの定量法を検討した. 支持電解質に $\mathrm{pH} 2.9$ に調整した $0.1 \mathrm{M}$ 硝酸カリウムを用い, 正電位 方向に電位走査したとき, $+1.0 \mathrm{~V}(\mathrm{vs} . \mathrm{Ag} / \mathrm{AgCl})$ 付近で得られるピーク電流值と塩化物イオン濃度と の間に良好な比例関係が得られた。定量範囲は $2 \sim 900 \mathrm{mg} / 1$ で，検量線の相関係数は 0.998 であった。 $+0.5 \sim+1.3 \mathrm{~V}$ の狭い範囲を数回電位走査すれば, 再現性の良い波形が得られる. $\mathrm{Ag}$ 及び $\mathrm{Hg}(\mathrm{II})$ 以 外の金属イオンはほとんど妨害しない.しかし，ヨウ化物及び臭化物イオンは微量でも妨害するため除 去する必要がある. 本法はフルオレセインを用いる硝酸銀滴定によるファヤンス法と比較した場合, 平 均伹の相対誤差は $+5 \%$, 標準偏差は $8 \%$ でやや大きいが, 広い濃度範囲の塩化物イオンを短時間で定 量できる利点がある.
\end{abstract}

\section{1 緒言}

電気化学分析による塩化物イオンの定量には，銀指示 電極を用いる電位差滴定法 ${ }^{122}$, 滴下水銀電極による ポーラログラフィー3), 八ロゲン化銀あるいは四級アン モニウム塩などを応答膜としたイオン電極法年, 又, 銀 作用電極を使用したものにはクーロメトリー，クロノア

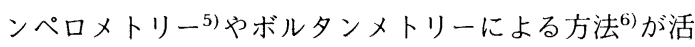
用されている.

著者らは，先に双金電極を用いた 4 電極法による水 銀（II）の定量法について報告した7)が, 今回は, 金作 用電極及び白金対極を組み合わせた双極電極を使用し， サイクリックボルタンメトリーを適用した場合，正電位 方向に走查したとき, $+1.0 \sim+1.1 \mathrm{~V}(v s . \mathrm{Ag} / \mathrm{AgCl})$ 付 近で得られる酸化波形のピーク電流值から塩化物イオン を簡便迅速に再現性良く定量できることが分かったの で, 測定装置, 定量法及び結果について報告する。な お，検量線は塩化物イオン濃度 2 900 mg/l の間で直 線となり, 広濃度範囲で塩化物イオンの定量が可能であ る.

\section{2 実験}

\section{$2 \cdot 1$ 電梗, 電解セル, 試薬及び測定装置}

金作用電極は，直径 $1.0 \mathrm{~mm}$ の純金線を用い，溶液に

* 日本大学工学部工業化学科 : 963 福島県郡山市田村町 徳定中河原 1
接する面は深さ $1.0 \mathrm{~mm}$ の円筒形 $\left(0.039 \mathrm{~cm}^{2}\right)$ とし, 他はエレクトロンワックスを塗布した後, 熱収縮チュー ブにより二重に被覆絶縁した，対極は，厚さ $0.1 \mathrm{~mm} の$ 白金板で幅 $10.0 \mathrm{~mm}$, 深さ, $10.0 \mathrm{~mm}\left(2.04 \mathrm{~cm}^{2}\right)$ で他 の面は，エレクトロンワックスで被覆した。

試薬は精密分析用（有害金属測定用）又は特級品を主 とし、リン酸は電子工業用（ELSS 級）を使用した。

その他, 実験に使用した基準電極, 塩橋, 通電用電 極, 電解セル及び金属標準液 $\{\mathrm{Cr}(\mathrm{III})$ は希塩酸で溶 解後, 過塩素酸白煙処理, 他はすべて希硝酸で溶解し た子などの取り扱い使用法は既報》に準じた。なお，塩 化物イオン標準液は塩化ナトリウムを用いた。

測定回路を Fig. 1 に示した. 作用電極及び対極を通 電用電極加電気的に浮かせて作用電極電位を規制する ため, はん用演算増幅器及び差動増幅器（142502, テレ ダイン・フィルブリック; AD521K, アナログデバイ ス）とポテンショスタット（HA-301, 北斗電工）を組 み合わせた回路を用いた。

三角波入力と電流-電位曲線の記録には, それぞれ直 流電位走查電源 $(\mathrm{HB}-104$, 北斗電工) 及び $X-Y$ 記録計 (3086, 横河電機) を使用した。なお, 電位検出用差動 增幅器 $\mathrm{OP} 2$ 及び電流-電圧変換器 $\mathrm{OP} 4$ の電源は, 他の 回路に対して電気的に浮かせるため両電源 IC （RC-4195N，レイセオン）を電池で駆動させて使用し た. 


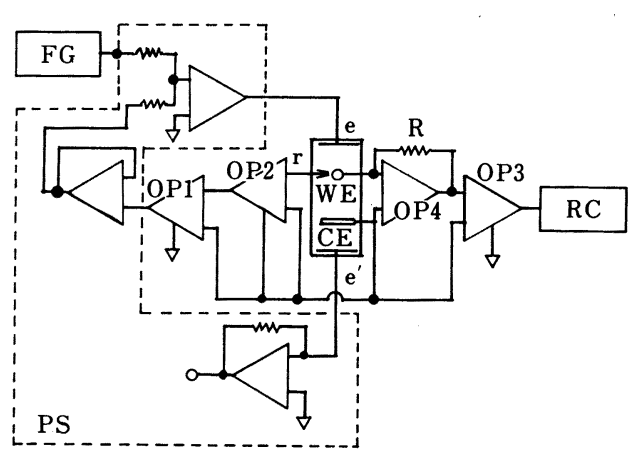

Fig. 1 Schematic diagram of voltammetric detection system for measuring the concentration of chloride

WE and CE : gold-platinum bipolar electrode; e and $e^{\prime}$ : platinum current carrying electrodes; $r$ : reference electrode; OP1, OP2 and OP3: differetial amplifier AD521K; OP4: operational amplifier 142502 ; R : resister $1 \mathrm{k} \Omega$; FG : function generator HB-104; PS : potentiostat HA-301; RC: $X-Y$ Recorder 3086

\section{$2 \cdot 2$ 定量操作}

不純物を除去するため, 作用電極, 対極及び通電用電 極表面を脱脂綿に酸化マグネシウム粉末を付着し軽く研 磨した後, $7 \mathrm{M}$ 硝酸に 5 分間浸し, 蒸留水で洗浄し た。

支持電解質溶液は $0.1 \mathrm{M}$ 硝酸カリウムを用い, 指示 薬としてチモールブルーを加え, リン酸及び水酸化ナト リウムの希薄溶液で使用の都度 $\mathrm{pH} 2.9$ に調整した.

電極の予備電解は, 電解セルに支持電解質溶液を入 れ, 各電極及び基準電極をセットした後, 電位走査速度 $5000 \mathrm{mV} / \mathrm{min}$ で, +0.5〜+1.3 V(vs. Ag/AgCl) の間を 繰り返し走査し, 電極を活性化した。 なお, 十分に活性 化すれば定量の際は, 数回の折り返し電位走查で再現性 のある波形が得られる.

定量の手順は次のとおりである. $\mathrm{pH}$ 調整済みの支持 電解質溶液 $50 \mathrm{ml}$, 続いて被検試料の一定量を加えた溶 液, 更に塩化物イオン標準液を添加した場合のこれら 3 種の正電位方向で得られる酸化波形を記録し, それぞれ のピーク電流値を求め, 支持電解質の残余電流を補正し た後, 標準添加法により計算して被検試料中の含量を求 めた。なお，標準添加法の誤差を小さくするため，支持 電解質溶液 $50 \mathrm{ml}$ に添加する被検溶液及び塩化物イオ ン標準液の合量は $5 \mathrm{ml}$ 以下にした ${ }^{8)}$. 検量線は, 支持 電解質溶液と標準液で作成した。

作用電極と対極間隔は, 電解セル中心よりそれぞれ
$30 \mathrm{~mm}$ に配置し, 極間 $60 \mathrm{~mm}$ として, 基準電極先端は 金作用電極の等電位線上に固定した. 測定中の液温は, $25 \pm 1{ }^{\circ} \mathrm{C}$ で, 溶液を添加したときかき混ぜのため, 窒素 を 10 秒間通じた. なお, 特に溶存酸素を除去する必要 はない.

\section{3 結果及び考察}

\section{$3 \cdot 1$ 支持電解質及び $\mathbf{p H}$ の影響}

金作用電極を用いた $\mathrm{pH} 2.9$ 付近の测定では,リン 酸, 過塩素酸, 硝酸と硫酸などとこれらのカリウム及び ナトリウム塩類溶液について検討したところ, 硫酸及び 硫酸塩を使用した場合は, 塩化物イオンの定量にややば らつきが見られたが, 他の支持電解質を使用した場合 は, いずれも $0.1 \mathrm{M}$ 濃度以上の溶液を用い, $\mathrm{pH} 2.9$ 付 近で測定すれば, 再現性良く定量できることが分かっ た。

金作用電極を用いた場合，塩化物イオンの酸化波形之 作用電極表面の酸化物層生成のための残余電流が $+1.0 \sim+1.1 \mathrm{~V}$ (vs. Ag/AgCl) 付近で重なる. 特に, 低 濃度の支持電解質を用いた場合, ピーク電流值に再現性 がなく, 塩化物イオンの酸化波を抽出することが難し い. しかし, 支持電解質を一定濃度以上に高くすると残 余電流が一定して, 定量值の再現性が改善されることが 分かった。

Fig. 2 に支持電解質及び塩化物イオンを添加した場合 の電流-電位曲線を示す. Fig. 3 に硝酸カリウムを用い

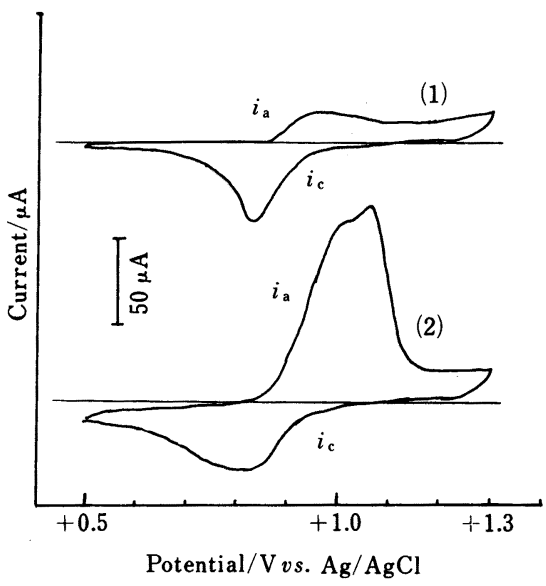

Fig. 2 Cyclic voltammogram of chloride

(1) Supporting electrolyte only: $0.1 \mathrm{M} \mathrm{KNO}_{3}$ at $\mathrm{pH} 2.9$; $(2)(1)+\mathrm{Cl}^{-}$: chloride ion concentration $200 \mathrm{mg} / \mathrm{l}$; Scan rate: $5000 \mathrm{mV} / \mathrm{min} ; i_{\mathrm{a}}$ : anodic current $; i_{\mathrm{c}}$ : cathodic current 


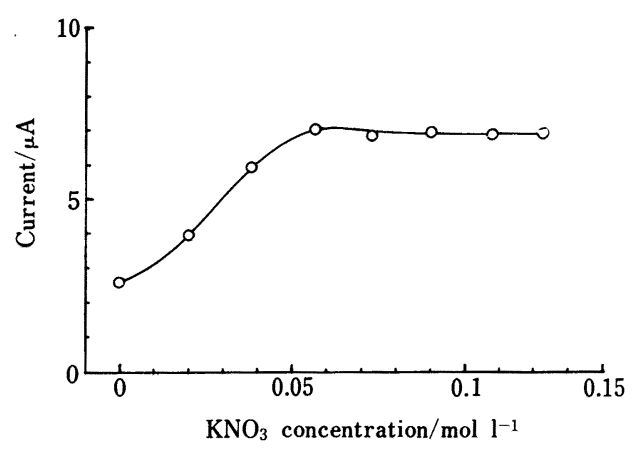

Fig. 3 Effect of supporting electrolyte concentration on maximum value of anodic background current

Electrolyte : $0.1 \mathrm{M} \mathrm{KNO}_{3} ; \mathrm{pH}: 2.9$; Scan rate : $5000 \mathrm{mV} / \mathrm{min}$

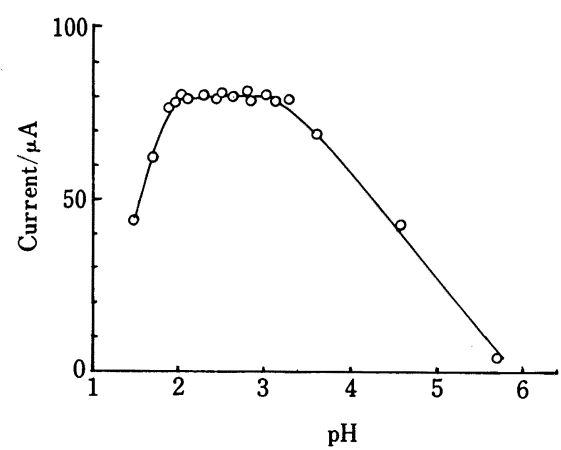

Fig. 4 Effect of $\mathrm{pH}$ on anodic peak current of chloride

$\mathrm{Cl}^{-}: 200 \mathrm{mg} / 1$; Electrolyte : $0.1 \mathrm{M} \mathrm{KNO}_{3} ;$ Scan rate : $5000 \mathrm{mV} / \mathrm{min}$

た場合の支持電解質濃度による残余電流値（ここでは， 酸化物層生成の際の不動態化電流の最大值をとった）の 変化を示した。

又, 塩化物イオンのピーク電流値についての $\mathrm{pH}$ の 影響は Fig. 4 に示した.

支持電解質は $0.06 \mathrm{M}$ 濃度以上, $\mathrm{pH}$ は 2 3 の間で ほぼ一定值になる。定量操作の際の $\mathrm{pH}$ 調整には, $\mathrm{Ag}$

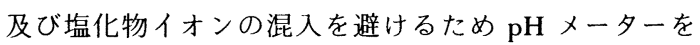
使用せず，指示薬にチモールブルーを用いた。なお，塩 化物イオンの還元波形は Fig. 2 に示したように, 酸化 波形のような明りょうなピーク波形が得られず，定量に は不適であった。

\section{$3 \cdot 2$ 電 極}

塩素電極としては，優れた電極触媒能を持つパラジウ ムが知られているが, 嘚食しやすく化学的安定性に劣る ため9), 化学的に安定な材種として金, 白金, チタン及 びタングステンと, 反応性電極としては銀について $2 \cdot 2$ 定量操作に従って使用の可否を検討した，電位走査範囲 $+0.5 \sim+1.3 \mathrm{~V}$ (vs. $\mathrm{Ag} / \mathrm{AgCl})$ において，金は再現性の 良いピーク波形を与えたが，他の材種ではピーク波形が 得られなかった。

金作用電極を用いて，塩化物イオン存在下の酸性溶液 を $+1.1 \mathrm{~V}$ 付近で定電位電解した場合は, 酸化物層形成 反応のほかに，次に示す塩化物イオンの酸化及び錯体生 成の溶解反応による 2 式が考えられるが(0),

$$
\begin{aligned}
& 2 \mathrm{Cl}^{-} \longrightarrow \mathrm{Cl}_{2}+2 \mathrm{e}^{-} \\
& \mathrm{Au}+2 \mathrm{Cl}^{-} \longrightarrow\left[\mathrm{AuCl}_{2}\right]^{-}+\mathrm{e}^{-}
\end{aligned}
$$

電解液に 0 -トリジン溶液を加え, $+1.1 \mathrm{~V}$ で定電位電解 した場合, 作用電極付近の溶液が黄色に着色し遊離塩素 の生成が認められた ${ }^{11)}$ ：主として式(1)の反応による ものと考えられ，かつ，今回のような測定条件であれば, 遊離塩素による電極の溶解消耗のおそれ ${ }^{12)}$ もなく使用 できることが分かった．金属顕微鏡観察でも電極の表面 状態は電解の前後でほとんど変化していない，又，金作 用電極表面も軽微な污染の場合は，研磨せず活性化する だけでよい。

一方，対極材種について，既報》と同様に金対極を使 用した場合は，対極電位測定回路を付加して対極の電位 変化を求めたところ, 作用電極で塩化物イオンの酸化が 起きたときの対極に妨害反応が見られ，ピーク電流值の 再現性が悪かった．そのために他材種の対極について検 討したところ，白金の分極が最も小さく，対極に妨害反 応も見られず，かつ, 表面積の大小 (対極面積 1.03 及 び $2.04 \mathrm{~cm}^{2}$ で比較した）にかかわらず，ほとんど一定 のピーク電流值が得られた．本法のように双極電極を反 応解析に適用する場合も, 界面インピーダンスの小さい 白金は優れた対極材種として使用できることが分かっ た.

\section{$3 \cdot 3$ 電位走查速度}

塩化物イオン濃度 $200 \mathrm{mg} / \mathrm{l}$ の溶液を用いて, 電位範 囲 $+0.5 \sim+1.3 \mathrm{~V}$ (vs. $\mathrm{Ag} / \mathrm{AgCl}$ ) の間で, 走査速度の影 響を調べ Fig. 5 に示した。

ピーク電流 $i_{\mathrm{p}}$ と走査速度 $v$ から求めた $i_{\mathrm{p}} / v^{1 / 2}$ は, 1000 7000 mV/min の範囲でほぼ一定であり,ピーク 


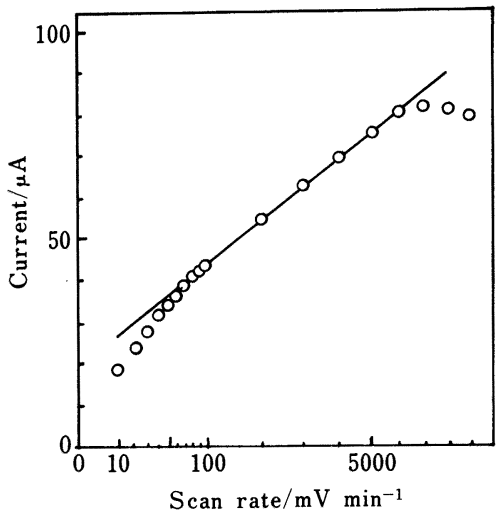

Fig. 5 Effect of scan rate of potential on anodic peak current of chloride

$\mathrm{Cl}^{-}$: $200 \mathrm{mg} / 1$; Electrolyte : $0.1 \mathrm{M} \mathrm{KNO}_{3} ; \mathrm{pH}$ : 2.9

電流の濃度依存性と共に拡散律速の傾向を示した。速度 の小さいほうが充電電流による誤差がなく正確に測定で きるものと期待したが, 測定が長時間にわたるため, 対 流, 振動なよ゙の溶液のかき混ぜの影響のほか生成された 遊離塩素の析出や吸着によって電極表面状態に変化が起 き, 測定值の再現性の悪化やピーク電流の低下を招いた ものと思われる ${ }^{13)}$.

\section{$3 \cdot 4$ 検量線}

$2 \cdot 2$ の定量操作に従って支持電解質に塩化物イオンを 添加し, 溶液の濃度として, 2 900 mg/l の範囲で 20 点測定により検量線を作成した。

直線回州式の塩化物イオン濃度に対するピーク電流の 傾斜及び切片はそれぞれ $0.403 \mu \mathrm{A} /(\mathrm{mg} / \mathrm{l}),+4.44 \mu \mathrm{A}$ であり，相関係数は 0.998 であった。

\section{$3 \cdot 5$ 共存物質の影響}

$3 \cdot 1$ で述べたようにリン酸, 過塩素酸, 硝酸と硫酸な どオキシ酸イオンは硫酸イオンを除いてほとんど妨害し ない.ここでは共存イオンとして, 金属イオン 10 種 $\{\mathrm{Mg}$ (II), $\mathrm{Ca}(\mathrm{II}), \mathrm{Cr}$ (III), Mn(II), Fe(III), Ni(II), $\mathrm{Cu}(\mathrm{II}), \mathrm{Zn}(\mathrm{II}), \mathrm{Hg}(\mathrm{II})$ 及び $\mathrm{Pb}(\mathrm{II})\}, \exists ウ$ 化物イ才 ン及び臭化物イオンについて，塩化物イオンを 100 $\mathrm{mg} / \mathrm{l}$ として, $2 \cdot 2$ の定量操作に従って検討した.

$\mathrm{Hg}$ (II) は微量共存しても, $+0.95 \mathrm{~V}$ (vs. Ag/AgCl) 付近で酸化波形を生じ，塩化物イオン及び電極表面の酸 化による残余電流との 3 者が重なり合い, 解析するの
が難しい.

長時間電解した場合には，塩化水銀(I) の沈殿を生じ 不都合であった.その他の金属イオンに関しては $100 \sim 500 \mathrm{mg} / \mathrm{l}$ 程度共存させた場合 (塩化物, 金属イ才 ン及び支持電解質を混合し，pH 調整した）でも酸化還 元電位が離れているため妨害しない.

ヨウ化物及び臭化物イオンは $1 / 50$ 倍量の $2 \mathrm{mg} / \mathrm{l}$ 程 度共存すると, 塩化物イオンのピーク電流值にヨウ化物 イオンは正，臭化物イオンは負の誤差を与える傾向を示 し, 又, 再現性も悪い。 これらハロゲン化物イオンの妨 害を除くため, 前処理法に硝酸酸性で過マンガン酸カリ

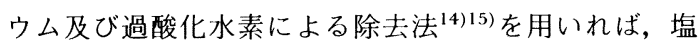
化物イオン含有量に対する相対䛊差が $\pm 5 \%$ 以内で定 量できることが分かった.

\section{$3 \cdot 6$ 海水の分析}

薄磯海水浴場（福島県いわき市）で採取した海水を用 いた。試料はミリポアフィルター $(0.45 \mu \mathrm{m})$ で吸引沃 過し, 浮遊物などを取り除き, 硝酸, 過マンガン酸カリ ウム及び過酸化水素により妨害イオンを除去し, 被検試 料とした. 硝酸銀滴定によるファヤンス法と本法とを比 較したところ，ファヤンス法で得られた定量值 $19.3 \mathrm{~g} / 1$ に対して, 本法の定量值は 21.2 (最大值) 18.7 g/1 (最 小值）となりやや正誤差を与えた. 8 点測定の平均値の 相対誤差は $+5 \%$ となった. 又, 定量値の標準偏差は $8 \%$ 前後とやや大きく, 高精度なファヤンス法とは比 ベられないが, 塩化物イオンの簡便迅速な機器分析法と して活用できることが分かった.

終わりに, 本研究に協力された学生恩田 勝 現在, 望 月印刷 $($ 株 $)\}$, 加藤誠秀 $\{\mathrm{SMC}($ 株) \}, 須貝寿広 (福島県経 済農業協同組合連合会), 山田雅彦 昍本電解(株)\} 及び西 徹英 恒和薬品(株)\} の諸君に謝意を表する.

\section{文献}

1) J. J. Lingane : "Electroanalytical Chemistry", p. 123 (1970), (Interscience Publishers, Inc., New York).

2) 工藤節子, 細野長悦, 寺㳄松孝, 斉藤幾世, 鈴木 信男: 分析化学, 36, T61 (1987).

3) B. H. Vassos, G. W. Ewing: "Electroanalytical Chemistry", p. 86 (1983), (John Wiley \& Sons, New York).

4) 植松宏彰, 河野 猛, 臼井誠次, 青梅 隆: 電 化, 55，532（1987）.

5) 日本分析化学会編 : “微量電気分析法”, 新分析化 学講座 2, p. 165 (1962), (共立出版).

6）山田明文, 程内和範 : 電化, 52, 633 (1984). 山 田明文, 程内和範, 加藤皓一, 橋田長一, 本田哲 夫: 同上, 54, 790 (1986). 山田明文, 程内和 範, 加藤皓一, 加藤良清: 分析化学, 36, 67 (1987). 
7）尾崎武二, 宇野原信行 : 分析化学, 36, 479 (1987).

8）例えば，塩川二朗: “機器分析のてびき 3 ”, p. 22 (1980), (化学同人).

9）延与三知夫 : 電化, 56, 394 (1988).

10）電気化学協会編: “電気化学便覧 第 4 版”, p. 72 (1985), (丸善).

11) JIS K 0101, 工業用水試験方法, 22 残留塩素, p. 41 (1966).

12）例えば, 森 元七: “高等化学深論”, 第 3 巻 $(A)$ 金属編, p. 498 (1942), (内田老鶴社).

13) 高村 勉: 電化, 39, 445 (1971).

14) 内海 喩, 伊藤舜介, 町田 弥, 奥谷忠雄: 分析 化学, 14, 12（1965).

15）友成明久: 日化, 83，696（1962）.

$$
\text { 幽 }
$$

Voltammetric determination of chloride ion with gold-platinum bipolar electrode. Takeji OZAKI, Kazuo Hirayama and Nobuyuki Unohara (Department of Industrial Chemistry, College of Engineering, Nihon Univerity, 1, Nakagawara, Tokusada, Tamura-machi, Kooriyama-shi, Fukushima 963)
A cyclic voltammetry was applied to the determination of chloride ion by the four electrodes method. A designed apparatus can concurrently measure the working electrode potential regulation and bipolar current, by using the gold working and platinum counter electrodes against the current-carrying electrodes as a bipolar electrode. As the result of scanning potential in the anodic direction in $0.1 \mathrm{M}$ potassium nitrite at $\mathrm{pH} 2.9$ as the supporting electrolytes, the correlation between the peak current at about $+1.0 \mathrm{~V}$ (vs. $\mathrm{Ag} / \mathrm{AgCl}$ ) and chloride concentration was linear. Chloride ion, ranging from 2 to $900 \mathrm{mg} / \mathrm{l}$, can be determined by scanning several times in the narrow range from +0.5 to $+1.3 \mathrm{~V}$ at a rate of 5 $\mathrm{V} / \mathrm{min}$. A small amount of silver, mercury, iodide and bromide ions interferes the determination of chloride, while most heavy metal ions do not interfere.

(Received April 19, 1989)

\section{Keyword phrases}

voltammetric determination of chloride; cyclic voltammetry; bipolar electrode; four electrodes method. 